8 EnTec - Encontro de Tecnologia da UNIUBE / 28 a 30 de outubro de 2014

\title{
O Uso de Borracha em Ligantes Asfálticos para Pavimentação de Rodovias no estado de Minas Gerais
}

Álvaro José Dias; Aline Brito de Paula; Geraldo Gouveia Franco Neto, Matheus Sousa Bernardes, ROBERTA AFONSO VINHAL WAGNER.

Universidade de Uberaba

alvaroj.dias27@gmail.com

\section{1 - Introdução}

A construção civil atualmente está em pleno desenvolvimento, à procura de aprimoramentos que torne possível a execução de obras econômicas, que facilite para o consumidor e para o construtor que muitas vezes não possui um grande recurso financeiro.

$\mathrm{O}$ uso de materiais ecologicamente corretos na construção civil transforma a realidade de uma sociedade globalizada que passa por novas perspectivas com relação ao uso de técnicas que degradam o meio ambiente. O nosso país hoje passa por um momento de sensibilização, sabendo da importância do uso dos recursos naturais de forma sustentável e não predatória. A união desses fatores representa um passo evolutivo na área da construção civil, por conseguinte, a engenharia sustentável é a engenharia do futuro.

O uso de pneumáticos nos ligantes asfálticos para a pavimentação de rodovias representa um processo tecnicamente e economicamente viável, e chega como solução e concomitantemente uma nova perspectiva para a resolução de inúmeros problemas em nossa malha rodoviária.

Além das vantagens mecânicas e ecológicas o asfalto-borracha apresenta melhorias nos contexto social como: o surgimento e fortalecimento de empresas especializadas na reciclagem de pneus para convertê-los em asfalto borracha; a diminuição do assoreamento de rios, lagos e baías, causados, em parte, pelo indevido descarte de pneus; benefícios diretos ao setor público pela criação de novas fontes de tributos a ingressar no cofre público, e adicionalmente serão criados novos empregos diretos nas empresas recicladoras. (SOARES, R. A.; MACHADO DE ASSIS, E.).

O projeto tem como objetivo exemplificar os processos de incorporação de pneumáticos em ligantes asfálticos, analisando a viabilidade da técnica no estado de Minas Gerais, e provando os benefícios frente à economia, sustentabilidade e a qualidade do asfalto.

\section{2 - Materiais e métodos}

Primeiramente ocorrerá um estudo dos processos de aplicação de pneumáticos na massa asfáltica, exemplificando os seguintes tópicos: caracterização do processo úmido, caracterização do processo seco, análise de qual processo se encaixa de maneira satisfatória na realidade tecno-econômica do estado de Minas Gerais. Essa é uma análise muito importante, pois dependendo do processo escolhido o projeto poderá seguir caminhos distintos.

Após determinar o processo que obteve o resultado mais satisfatório análises laboratoriais serão feitas, onde ira se determinar: as relações ideais de porcentagem de borracha e agregados na mistura, o volume de vazios, que de acordo com NOGUEIRA, M. L. é um fator importante muitas vezes ignorado nos estudos deste tipo de processo, a comparação de amostras com massa asfáltica modificada com pneumáticos com a massa asfáltica convencional.

O método de dosagem e coleta usado será o método Marshall, pois é o método mais usado para dosagem de massa asfáltica.

Será analisada a viabilidade técnica e econômica para uso do processo no estado. Abordando os seguintes tópicos: as tecnologias disponíveis no estado via DERMG (Departamento de Estradas e Rodagem de Minas Gerais) e construtoras, analise na demanda e qualificação de mão de obra, o recurso financeiro oferecido pelo governo estadual e federal para pavimentação e recapeamento de rodovias no estado de Minas Gerais, levantamento da malha rodoviária do estado de Minas Gerais, determinando as rodovias que necessitam de manutenção e pavimentação. 
8ํㅡㄹ EnTec - Encontro de Tecnologia da UNIUBE / 28 a 30 de outubro de 2014

Os tópicos anteriores serão

correlacionados com os seguintes tópicos

referentes à sustentabilidade: a quantidade de pneus inservíveis descartados em todo o estado de Minas Gerais, indústrias e usinas especializadas, o estudo de logística para o transporte, por todo o estado, de materiais necessários para o processo.

\section{3 - Resultados e discussão}

Espera-se estabelecer um levantamento completo da malha rodoviária do estado de Minas Gerais que necessita de recapeamento ou pavimentação

Compreender por completo os processos existentes de incorporação de pneumáticos em massa asfáltica, obtendo-se assim o método mais eficiente para o estado de Minas Gerais.

Provar a viabilidade tecno-econômica desse processo no estado de Minas Gerais, comprovando-se os benefícios frente à sustentabilidade.

Pretende-se estabelecer uma gestão para que toda a demanda de pneus inservíveis do estado tenha a correta destinação, criando um planejamento, baseado em estudos bibliográficos, trabalhos em campo, analises laboratoriais; para o aprimoramento da malha rodoviária e do sistema ecológico mineiro.

\section{4 - Considerações finais}

Os estudos bibliográficos comprovaram que o uso de pneus inservíveis em ligantes asfálticos para pavimentação de rodovias é uma técnica promissora para o estado de Minas Gerais, e que obteve durante suas primeiras aplicações benefícios estruturais e ecológicos.

No que diz respeito à mecânica do asfalto a incorporação da borracha apresentou melhoras como redução do envelhecimento, aumento da flexibilidade, aumento do ponto de amolecimento e redução da susceptibilidade térmica.

A sustentabilidade é um ponto marcante no processo, seu beneficio foi comprovado uma vez que a pavimentação de um quilômetro representou 0 uso de até mil pneus, facilitando na destinação de pneus inservíveis eliminando os problemas causados como a criação de focos de doenças (um problema real no estado), o assoreamento de rios entre outros.

\section{5 - Referências}

AMARAL, S. C. Estudo de misturas densas com agregados do estado do Pará, utilizando asfalto convencional (CAP-40) e asfalto modificado com polímero SBS (Betuflex B 65/60). 2000. Dissertação (Mestrado em Transportes) - Universidade de São Paulo, São Carlos, 2000.

BERTOLLO, S. A. M.; FERNANDES JR., J. L.; SCHALCH, V.. Benefícios da Incorporação de Borracha de Pneus em Pavimentos Asfálticos, In: XXVIII CONGRESSO INTERAMERICANO DE ENGENHARIA AMBIENTAL E SANITARIA (2002), Cancun, México, 8 p., disponível em: www.resol.com.br/textos/reciclagem de pneus.pdf Acesso em: 27 mar. 2014.

DI GIULIO, G. Vantagens ambientais e econômicas no uso de borracha em asfalto. Inovação Uniemp, Campinas, v. 3, n. 3, jun. 2007.

NOGUEIRA, M. L. Avaliação do Controle de Qualidade de Misturas Asfálticas e Análise do Reflexo do Nível de Qualidade no Desempenho dos Revestimentos Asfálticos. Porto Alegre: PPGEC/UFRGS, (2011), 88 f. Dissertação de Mestrado (Geotecnia) - Programa de Pós Graduação em Engenharia Civil, Universidade Federal do Rio Grande do Sul, Porto Alegre, RS, 2011.

ODA, S.; JUNIOR, J. L. F. Borracha de pneu como modificador de cimentos asfálticos para uso em obras de pavimentação. Acta Scientiarum, v. 23, n. 6, p. 1598-1599, 2001

PINHEIRO, J. H. M. Incorporação de borrachas de pneu em misturas asfálticas de diferentes granulometrias. 2004. Dissertação (Mestrado em Engenharia de Transportes)-Universidade Federal do Ceará, Fortaleza, 2004.

SOARES, R. A.; MACHADO DE ASSIS, E. O uso da Borracha de Pneus na Pavimentação como uma Alternativa Ecologicamente Viável. 2008. 15 p. Universidade Católica de Salvador, Salvador, BA, 2008.

\section{Agradecimentos}

À Universidade de Uberaba pela bolsa concedida, e à professora Roberta que foi um grande incentivo nesse projeto. 